\title{
MANAGEMENT PANEL, THE QUALITY OF TEACHING AND COMMITMENT TO THE ACHIEVEMENT OF MALAY LANGUAGE IN SABAH STATE
}

\author{
PENGURUSAN PANITIA, KUALITI PENGAJARAN DAN KOMITMEN \\ KERJA TERHADAP PENCAPAIAN BAHASA MELAYU DI NEGERI \\ SABAH
}

\author{
Latifah Ayang ${ }^{1}$ \\ Universiti Malaysia Sabah \\ Contact number: 0165574902 \\ (Email: intankisbob@yahoo.com) \\ Mohamad Khairuddin Abdullah ${ }^{2}$ \\ Universiti Malaysia Sabah
}

Accepted date: $12-06-2019$

Published date: 08-07-2019

To cite this document: Ayang, L., \& Abdullah, M. K. (2019). Management Panel, The Quality of Teaching and Commitment ot The Achievement of Malay Language in Sabah State. International Journal of Education, Psychology and Counseling, 4(31), 373-383.

DOI: $10.35631 /$ IJEPC.4310032

\begin{abstract}
Abstrak: Kajian ini dilaksanakan adalah untuk mengenal pasti pengurusan panitia, kualiti pengajaran dan komitmen guru terhadap pencapaian Bahasa Melayu di Negeri Sabah. Pengurusan Panitia dilihat dalam aspek prinsip pengurusan panitia, sifat kendiri dan kemahiran pengurusan. Manakala kualiti pengajaran pula dilihat dari sudut dimensi persediaan pengajaran, penyampaian pengajaran dan aspek tingkah laku. Seterusnya pembolehubah komitmen kerja dilihat dari aspek kesediaan untuk kekal dalam organisasi, komitmen kepada profesion perguruan dan komitmen terhadap pelajar. Dalam kajian ini, penyelidik telah menggunakan Teori Pengurusan Saintifik Taylor, Teori Vroom dan Teori Side Bet. Pengkaji telah menggumpul sebanyak 335 soal selidik yang telah dijawab dalam kalangan responden guru yang mengajar Bahasa Melayu dan mewakili seluruh Sekolah Menengah bantuan penuh kerajaan di Negeri Sabah dengan mengunakan persampelan berkelompok, persampelan cluster dan persampelan rawak mudah. Manakala data pula dianalisis menggunakan program SPSS for Windows Versi 25.0. Ujian ANOVA satu hala, korelasi Pearson dan analisis regrasi berganda telah digunakan untuk menganalisis data yang dikutip. Dapatan kajian ini mendapati bahawa terdapat perbezaan yang signifikan pengurusan panitia, kualiti pengajaran dan komitmen kerja berdasarkan faktor pengalaman mengajar tetapi tidak terdapat perbezaan yang signifikan pengurusan panitia dan kualiti pengajaran berdasarkan faktor kelulusan akademik. Dari segi hubungan pula, didapati bahawa terdapat korelasi positif yang signifikan antara pengurusan panitia dan pencapaian Bahasa Melayu. Manakala bagi pemboleh ubah kualiti pengajaran pula terdapat hubungan positif yang
\end{abstract}


signifikan dengan pencapaian Bahasa Melayu. Seterusnya terdapat hubungan yang signifikan antara Komitmen kerja Guru dan pencapaian Bahasa Melayu. Ujian regrasi berganda pula menunjukkan bahawa terdapat pengaruh yang signifikan antara komitmen kerja dengan pencapaian Bahasa Melayu. Pengkaji turut mencadangkan agar pihak berwajib bersama-sama mengembleng tenaga untuk memastikan pencapaian pelajar dalam mata pelajaran Bahasa Melayu sentiasa cemerlang sejajar dengan kedudukan Bahasa Melayu sebagai Bahasa Kebangsaan.

Kata Kunci: Pengurusan Panitia, Kualiti Pengajaran, Komitmen Guru, Guru Bahasa Melayu, Pencapaian Pelajar

Abstract: This study was conducted to identify the management panel, the quality of teaching and teachers' commitment to the achievement of the Malay language in Sabah. Management panel is seen in the aspects of the committee's management principles, self-properties and self-management skills. While the quality of teaching is seen from the dimensions of teaching preparation, teaching presentation and behavioral aspects. Other than that, the variable of working commitments is seen in terms of its Willingness to remain in the organization, teaching profession commitment and commitment to the students. In this study, researcher used the Taylor Scientific Management Theory, Vroom Theory and Side Bet Theory. The researcher has collected 335 questionnaires that have been answered among teachers who teach Malay Language and representative to all high schools in Sabah by using group sampling, cluster sampling and simple random sampling. While the data was analyzed using SPSS for Windows version 25.0. One-way ANOVA test, Pearson correlation and multiple regression analysis were used to analyze the data collected. This study found that there are significant differences in the management committee, the quality of teaching and work commitments based on teaching experience, but there were no significant differences in management committee based on academic qualifications. In terms of connectivity, it is found that there is a positive significant correlation between management committee and the achievements of Malay Language. While the variable in quality of teaching was a positive significant correlation with Malay Language achievement. Thus, there was also significant relationship between the work Commitment and the achievement of the Malay language. Multiple regression tests showed that there was a significant influence between the work commitment with the achievement of the Malay Language. The researcher also suggested that the authorities should forces together to ensure the achievement of students in Malay Language is always excellent in line with the Malay language as the National Language.

Keywords: Management Panel, Quality of Teaching, Commitment, Malay Language Teacher, Student Achievement

\section{Pendahuluan}

Kemajuan Malaysia sebagai sebuah negara yang sedang pesat membangun turut menyaksikan kepesatan dari aspek anjakan ekonomi, politik dan sosial. Tidak ketinggalan juga kemajuan dalam aspek pendidikan dan pembangunan modal insan. Bidang pendidikan dilihat sebagai satu medium dalam merealisasikan hasrat negara selangkah lagi menuju ke arah negara maju dan setanding dengan negara-negara yang lain. Hasrat kerajaan ini dijelaskan dalam program Transformasi Pendidikan dalam Pelan Pembangunan Pendidikan Malaysia (PPPM) 2013- 
2025. Justeru, Malaysia telah membangunkan pelbagai elemen yang menyokong kepada pengukuhan, kemajuan mahupun kestabilan negara (Muhyiddin Yassin, 2012).

Pengurusan pendidikan merupakan satu keperluan yang wajar diberikan perhatian serius. Hal ini demikian kerana, sistem pendidikan pada masa kini sentiasa berhadapan dengan transformasi dan bersifat dinamik. Kedinamikan ini memerlukan sistem pendidikan sentiasa diselaraskan dengan perubahan semasa. Objektif penyelarasan yang dilakukan seperti reformasi dan transformasi serta pelan perancangan pendidikan ini hanya akan tercapai apabila para pengurus memiliki set amalan kepengurusan yang sistematik (Marzita Puteh, 2013).

Pengajaran dalam mata pelajaran bahasa khususnya Bahasa Melayu memerlukan kajian yang mendalam berikutan pencapaian pelajar dalam mata pelajaran tersebut semakin merudum saban tahun, walhal Bahasa Melayu pernah dijadikan sebagai bahasa untuk mengajarkan agama Hindu pada zaman pra-Islam walaupun dalam lingkungan yang terhad. Pernyataan ini menggambarkan bahawa Bahasa Melayu telah memainkan peranan penting dalam kehidupan masyarakat semenjak zaman pra-Islam lagi. (Noresah Baharom yang dipetik dalam Yusfarina dan Abdul Rasid, 2011).

Beberapa pengkaji misalnya Kington et.al, (2011) masih lagi mempersoalkan peranan guru dalam memastikan kecemerlangan pelajar terutama dalam aspek pembelajaran bahasa. Isu pengurusan yang lemah, pengajaran yang kurang berkesan dan komitmen yang tidak konsisten menjadi persoalan utama kemerosotan pencapaian pelajar terutama dalam mata pelajaran Bahasa Melayu

\section{Objektif Kajian}

Objektif kajian adalah untuk mengenal pasti tahap pengurusan panitia Bahasa Melayu, kualiti pengajaran dan komitmen guru Bahasa Melayu. Selain itu, kajian ini juga bertujuan untuk mengenal pasti perbezaan tahap pengurusan Panitia Bahasa Melayu, kualiti pengajaran dan komitmen guru Bahasa Melayu terhadap pencapaian pelajar dalam mata pelajaran Bahasa Melayu berdasarkan demografi. Akhirnya kajian ini juga turut mengenal pasti sama ada terdapat hubungan antara pengurusan Panitia Bahasa Melayu, kualiti pengajaran dan komitmen guru dengan pencapaian mata pelajaran Bahasa Melayu.

\section{Metodologi}

Kajian ini menggunakan pendekatan kuantitatif dan merupakan kajian tinjauan yang dijalankan dengan menggunakan instrumen soal-selidik. Data diperoleh dan dikumpul dengan menggunakan borang soal-selidik bagi mengenal pasti pengurusan panitia, kualiti pengajaran dan komitmen kerja guru serta kaitannya dalam pencapaian Bahasa Melayu sebagai bahasa kedua di Negeri Sabah. Pemboleh ubah yang digunakan oleh pengkaji terdiri daripada pemboleh ubah bersandar (dependent variable) iaitu pencapaian pelajar dalam mata pelajaran Bahasa Melayu. Manakala pemboleh ubah tidak bersandar (independent variable) iaitu pengurusan panitia, kualiti pengajaran dan komitmen kerja guru.

Pemboleh ubah pengurusan panitia, kualiti pengajaran dan komitmen kerja guru dipilih dalam kajian ini memandangkan ketiga-tiga variable tersebut mempunyai kaitan yang rapat dalam pengajaran dan pembelajaran Bahasa Melayu. Pengurusan panitia merujuk kepada bagaimana pengurusan dalam mata pelajaran Bahasa Melayu dapat mempengaruhi pencapaian pelajar. Pemboleh ubah ini mewakili bidang pengurusan. Pengurusan yang baik sahaja tidak 
menjanjikan kejayaan jika tidak disertai dengan pengajaran yang berkesan di bilik darjah terutamanya. Kaitan seterusnya dapat dilihat dengan memilih satu lagi pemboleh ubah iaitu komitmen kerja guru yang berterusan. Ketiga-tiga pemboleh ubah digandingkan dalam kajian ini untuk melihat perkaitannya dari segi demografi.

Analisis deskriftif kajian ini pula, menjelaskan tahap skor min pengurusan panitia, kualiti pengajaran dan pembelajaran guru dan komitmen kerja guru Bahasa Melayu di kawasan Zon Utara negeri Sabah yang telah dipilih sebagai sampel kajian. Analisis statistik inferensi pula digunakan ialah nilai pekali korelasi, ANOVA dan regrasi berganda. Analisis statistik pekali korelasi akan digunakan untuk mengkaji perkaitan antara variabel iaitu perkaitan antara pemboleh ubah bersandar dan pemboleh ubah tidak bersandar, sama ada variabel tersebut mempunyai perkaitan yang kuat, sederhana atau perkaitan yang lemah. Seterusnya ujian analisis varians ANOVA pula digunakan untuk mengkaji perbezaan variabel-variabel tidak bersandar berdasarkan faktor umur, pengalaman mengajar dan taraf akademik. Manakala kaedah analisis regrasi berganda pula digunakan untuk mengenal pasti pengaruh variabel tidak bersandar terhadap variabel bersandar

Kaedah Pensampelan yang digunakan dalam kajian ini ialah kaedah Pensampelan bertujuan (purposive sampling) digunakan kerana kajian hanya terbatas kepada guru-guru di Negeri Sabah yang mengajar mata pelajaran Bahasa Melayu sahaja. Hal ini demikian kerana persampelan bertujuan ialah memilih sampel daripada satu populasi yang dikaji mengikut tujuan kajian. Biasanya, persampelan ini adalah untuk kajian awalan atau penerokaan dan juga untuk menguji sesuatu teori. Dalam persampelan bertujuan, penyelidik akan memilih responden mengikut pertimbangannya sendiri iaitu yang paling sesuai dengan tujuan kajiannya. Lazimnya, individu yang dipilih sebagai responden dalam persampelan bertujuan mempunyai segala maklumat, perspektif atau apa-apa saja bahan yang berkaitan dengan tujuan kajian penyelidik. Kelebihan persampelan ini ialah penyelidik boleh menggunakan kemahiran dan pengetahuannya yang lalu dalam memilih subjek kajian dalam kajiannya yang akan datang ialah mengenai saiz sampel yang akan kita gunakan.

Selain kaedah pensampelan bertujuan (purposive sampling), penyelidik juga menggunakan kaedah pensampelan berkelompok. Kaedah pensampelan ini bertujuan untuk mengelompokkan responden kepada kelompok-kelompok tertentu. Dalam kajian ini responden kajian akan dikelompokkan mengikut zon. Terdapat enam zon atau bahagian yang terdapat di negeri Sabah dengan 219 buah sekolah.

Setelah dikelompokkan mengikut zon, pengkaji akan menggunakan pula kaedah persampelan kluster atau kaedah persampelan kawasan. Pengkaji telah memilih kawasan-kawasan tertentu yang terdapat dalam kelompok zon. Pemilihan sampel kluster ini turut mengambil kira kawasan atau sekolah yang mempunyai pencapaian yang rendah dalam mata pelajaran Bahasa Melayu iaitu GPMP berada pada tahap lemah dan memuaskan iaitu GPMP 4.51 dan ke atas kemudian pengkaji menggunakan pula teknik persampelan rawak mudah. Antara aspek yang perlu diambil kira yang melibatkan persampelan kajian sampel yang kita gunakan itu menepati ciri-ciri populasi kajian. Oleh sebab kajian ini menggunakan kajian kuantitatif, saiz sampel boleh ditentukan dengan menggunakan prosedur pengiraan yang tertentu dengan mengambil kira ralat persampelan, aras signifikan dan juga aras keyakinan, dan kajian ini memilih menggunakan ralat persampelan 5\%, (significance level $(\alpha)$ - .05) dengan aras keyakinan (level of confidence) 95\%. Aras signifikan yang biasa ditetapkan dalam penyelidikan Sains Sosial ialah $\mathrm{p}<.05$ (nilai alpha $\alpha$ ). 
Bagi menentukan saiz sampel, pengkaji merujuk jadual penentuan saiz sampel yang telah disediakan seperti jadual Krejcie \& Morgan (1970) dan jadual Cohen et.al., (2001).Berdasarkan jadual Krejcie dan Morgan (1970) jika populasi yang melebihi 10,000 maka saiz populasi tidak lagi bermakna dan saiz sampel memadai sebanyak 400 sampel. Cohen, et.al (2000) menyatakan bahawa bagi populasi yang kurang daripada 10000 orang ialah seramai 278 orang. Dalam pengiraan formula yang ditetapkan oleh Cochran (1997) dalam Bartlett et. al., (2001) menyokong dapatan Cohen, et.al., (2000). Berkenaan dengan penentuan jumlah sampel juga Ppngkaji sebelumnya iaitu Alias Baba (1999) menyatakan bahawa bagi jumlah populasi seramai 1000 orang maka jumlah sampel yang diambil memadai sebanyak 300 orang. Berdasarkan penentuan saiz sampel pengkaji-pengkaji terdahulu pengkaji memutuskan untuk mengambil sampel minimum sebanyak 335 responden.

Manakala kajin rintis telah dilaksanakan bertujuan untuk menguji kesahan muka item di samping membuat semakan item-item yang dianggap perlu atau tidak perlu berkaitan dengan responden. Menerusi kajian rintis ini korelasi item dan indeks kebolehpercayaan Alpha Cronbach dapat dikenal pasti. Seramai 200 responden terlibat dalam kajian rintis ini. Data yang diperoleh telah dianalisis dengan menggunakan perisian SPSS Version 24.0 for Windows merangkumi pengiraan kekerapan dan kebolehpercayaan. Berdasarkan dapatan nilai dalam Cronbach alpha menerusi kajian ini mendapati bahawa dapatan nilai alpha bagi keseluruhan item adalah bersesuaian dan melebihi nilai alpha 0.6.

\section{Dapatan Kajian}

\section{Perbezaan Kualiti Pengajaran Berdasarkan Faktor Demografi Guru}

Jadual 4.01: Perbezaan Kualiti Pengajaran berdasarkan Faktor Umur

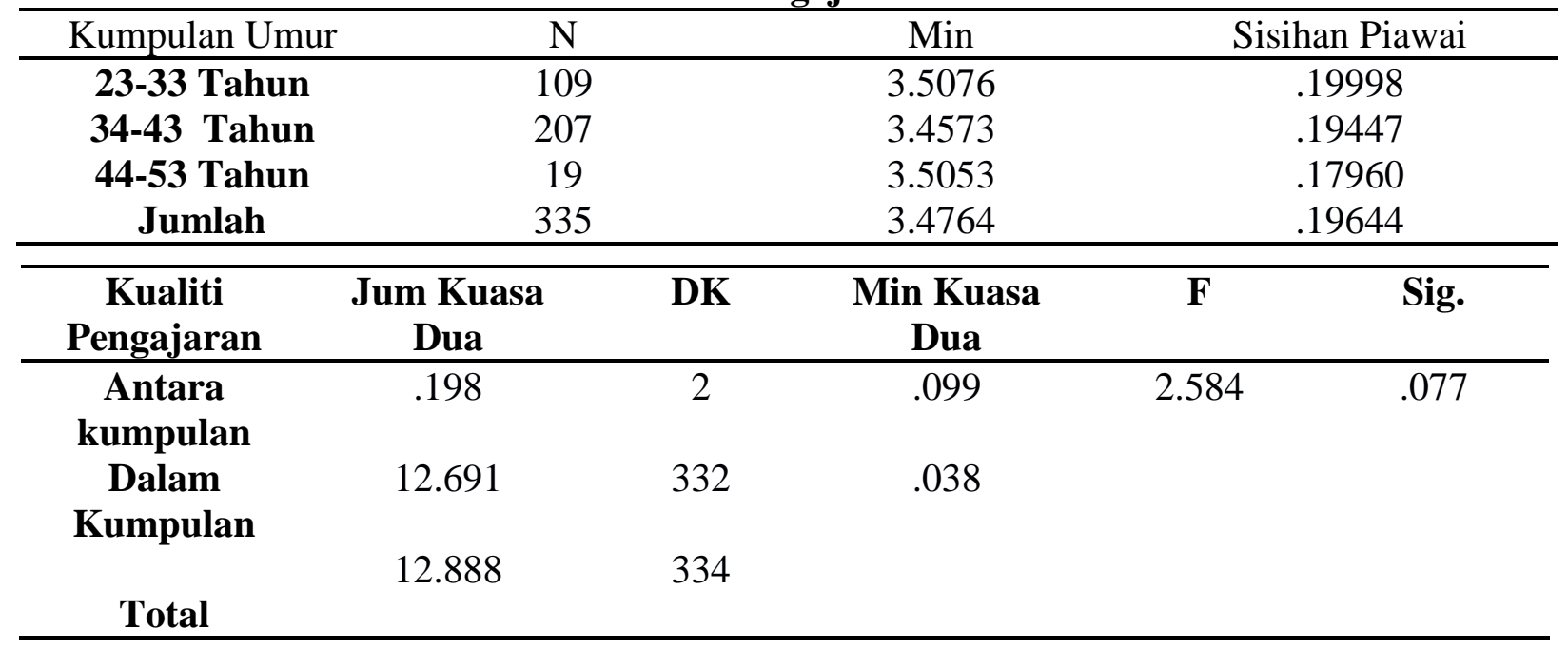

Berdasarkan jadual 4.01, didapati bahawa ujian ANOVA sehala menunjukkan bahawa tidak terdapat perbezaan yang signifikan kualiti pengajaran berdasarkan kumpulan umur guru $[F(2$. $332)=2.5 ; p>.05]$. Dapatan ini juga menunjukkan bahawa kualiti pengajaran adalah tinggi dalam kalangan guru yang berumur dalam lingkungan 23 hingga 33 tahun $(M=3.51$; $S P=$ .19). Seterusnya diikuti oleh guru-guru dalam lingkungan umur 44 hingga 53 tahun $(M=3.50$; $S P=.17)$. Dapatan ini adalah sama dengan kualiti pengajaran dalam kalangan guru yang 
berumur 34 hingga 43 tahun iaitu $(M=3.45 ; S P=.19)$. Secara keseluruhannya min pengurusan panitia berdasarkan faktor umur guru adalah pada tahap $(M=3.47 ; S P=.19)$.

Manakala, dapatan analisis data dalam jadual 4.02, pula menunjukkan keputusan ujian ANOVA Berganda bagi pembolehubah kualiti pengajaran dan faktor umur guru. Data ini menunjukkan bahawa tidak terdapat perbezaan yang signifikan kualiti pengajaran berdasarkan faktor umur. Dapatan ini menunjukkan bahawa $\mathrm{H}_{\mathrm{o}} 2$ (i) adalah diterima.

Jadual 4.02: Perbezaan Berganda Kualiti Pengajaran Berdasarkan Faktor Umur

\begin{tabular}{cccc}
\hline (I) Umur & (J) Umur & Perbezaan Min (I-J) & Sig. \\
\hline \multirow{2}{*}{ 23-33 Tahun } & $34-43$ & .05032 & .077 \\
\multirow{3}{*}{ 34-43 Tahun } & $44-53$ & .00238 & .999 \\
& $23-33$ & -.05032 & .077 \\
\multirow{3}{*}{ 44-53 Tahun } & $44-53$ & -.04794 & .563 \\
& $23-33$ & -.00238 & .999 \\
& $34-43$ & .04794 & .563 \\
\hline
\end{tabular}

*Signifikan pada aras keertian 0.05

Jadual 4.03: Perbezaan Kualiti Pengajaran Berdasarkan Faktor Kelulusan Akademik

\begin{tabular}{cccc}
\hline Tahap Kelulusan & N & Min & Sisihan Piawai \\
\hline Spm & 8 & 3.3167 & .18772 \\
Stpm & 8 & 3.2167 & .22467 \\
Ijazah Sarjana Muda & 313 & 3.4886 & .18868 \\
Ijazah Sarjana Lanjutan & 6 & 3.4000 & .26667 \\
$\quad$ Total & 335 & 3.4764 & .19644 \\
\hline
\end{tabular}

\begin{tabular}{cccccc}
\hline $\begin{array}{c}\text { Tahap } \\
\text { Kelulusan }\end{array}$ & $\begin{array}{c}\text { Jum Kuasa } \\
\text { Dua }\end{array}$ & DK & $\begin{array}{c}\text { Min Kuasa } \\
\text { Dua }\end{array}$ & F & Sig. \\
\hline $\begin{array}{c}\text { Antara } \\
\text { kumpulan } \\
\begin{array}{c}\text { Dalam } \\
\text { Kumpulan }\end{array}\end{array}$ & .825 & 3 & .275 & 7.550 & .000 \\
Total & 12.063 & 331 & .036 & & \\
\hline
\end{tabular}

Berdasarkan jadual 4.03, data secara keseluruhannya menunjukkan bahawa terdapat perbezaan yang signifikan kualiti pengajaran berdasarkan kelulusan akademik $[F$ (3. 331) $=7.55 ; p<.05]$. Min yang paling tinggi dicatatkan dalam kumpulan guru yang mempunyai kelulusan akademik Ijazah Sarjana Muda $(M=3.48 ; S P=.18)$ diikuti oleh guru yang mempunyai kelulusan Ijazah Sarjana Lanjutan $(M=3.40 ; S P=.26)$, diikuti pula oleh guru yang mempunyai kelulusan Sijil Pelajaran Malaysia $(M=3.31 ; S P=.18)$. seterusnya, min bagi guru yang mempunyai kelulusan akademik STPM ialah $(M=3.21 ; S P=.22)$. 
Jadual 4.04: perbezaan Berganda Kualiti Pengajaran Berdasarkan Kelulusan Akademik

\begin{tabular}{cccc}
\hline (I) Kelulusan & $($ J) Kelulusan & Perbezaan Min (I-J) & Sig. \\
\hline Spm & Stpm & .10000 & .721 \\
& Ijazah Sarjana Muda & -.17194 & .059 \\
Stpm & Ijazah Sarjana Lanjutan & -.08333 & .851 \\
& Spm & -.10000 & .721 \\
& Ijazah Sarjana Muda & $-.27194^{*}$ & .000 \\
Ijazah Sarjana & Ijazah Sarjana Lanjutan & -.18333 & .286 \\
Muda & Spm & .17194 & .059 \\
& & & .000 \\
Ijazah Sarjana & Stpm & $.27194^{*}$ & .674 \\
Lanjutan & Ijazah Sarjana Lanjutan & .08860 & .851 \\
& Spm & .08333 & .286 \\
& & & .674 \\
\hline
\end{tabular}

Seterusnya, dapatan analisis data dalam jadual 4.04, menunjukkan keputusan ujian ANOVA Berganda bagi pembolehubah kualiti pengajaran berdasarkan pengalaman mengajar. Data ini menunjukkan bahawa terdapat perbezaan yang signifikan kualiti pengajaran berdasarkan kelulusan akademik guru antara kumpulan guru yang berkelulusan Ijazah Sarjana Muda dengan Dengan kumpulan guru yang berkelulusan STPM [(I-J) $=.27 ; P<.05]$. Dapatan ini menunjukkan bahawa $\mathrm{H}_{\mathrm{o}} 2$ (ii) adalah ditolak.

Jadual 4.05: Perbezaan Kualiti Pengajaran Berdasarkan Faktor Pengalaman Mengajar

\begin{tabular}{cccc}
\hline Pengalaman mengajar & $\mathbf{N}$ & Min & Sisihan Piawai \\
\hline 1-10 Tahun & 107 & 3.5327 & .17768 \\
11-20 Tahun & 149 & 3.4890 & .19384 \\
21-30 Tahun & 56 & 3.4036 & .16001 \\
31-40 Tahun & 16 & 3.3667 & .23476 \\
lebih 40 Tahun & 7 & 3.1810 & .21676 \\
Total & 335 & 3.4764 & .19644 \\
\hline
\end{tabular}

*Signifikan pada aras keertian 0.05

\begin{tabular}{cccccc}
\hline $\begin{array}{c}\text { Tahap } \\
\text { Kelulusan }\end{array}$ & $\begin{array}{c}\text { Jum Kuasa } \\
\text { Dua }\end{array}$ & DK & $\begin{array}{c}\text { Min Kuasa } \\
\text { Dua }\end{array}$ & F & Sig. \\
\hline $\begin{array}{c}\text { Antara } \\
\text { kumpulan }\end{array}$ & 1.464 & 4 & .366 & 10.571 & .000 \\
$\begin{array}{c}\text { Dalam } \\
\text { Kumpulan } \\
\text { Total }\end{array}$ & 11.424 & 330 & .035 & & \\
\hline
\end{tabular}


Berdasarkan jadual 4.05, didapati bahawa ujian ANOVA sehala menunjukkan bahawa terdapat perbezaan yang signifikan kualiti pengajaran berdasarkan pengalaman mengajar guru $[F(4$. $330)=10.57 ; p<.05]$. Dapatan ini juga menunjukkan bahawa kualiti pengajaran adalah tinggi dalam kalangan guru yang mempunyai pengalaman mengajar 1 hingga 10 tahun $(M=3.53$; $S P=.17)$. Seterusnya diikuti oleh guru-guru yang mempunyai pengalaman mengajar 11 hingga 20 tahun $(\mathrm{M}=3.48 ; \mathrm{SP}=.19)$. Seterusnya, kualiti pengajaran berdasarkan guru yang mempunyai pengalaman mengajar 21 hingga 30 tahun $(M=3.36 ; S P=.23)$. Manakala kualiti pengajaran yang paling rendah adalah dalam kalangan guru yang mempunyai pengalaman mengajar lebih 40 tahun $(M=3.18 ; S P=.21)$

Jadual 4.06: Perbezaan Berganda Kualiti pengajaran Berdasarkan Pengalaman Mengajar

\begin{tabular}{cccc}
\hline (I) Pengalaman & (J) Pengalaman & Perbezaan Min (I-J) & Sig. \\
\hline 1-10 Tahun & $11-20$ & .04367 & .345 \\
& $21-30$ & $.12914^{*}$ & .000 \\
& $31-40$ & $.16604^{*}$ & .009 \\
11-20 Tahun & lebih 40 thn & $.35176^{*}$ & .000 \\
& $1-10$ & -.04367 & .345 \\
& $21-30$ & $.08547^{*}$ & .030 \\
\multirow{2}{*}{ 21-30 Tahun } & $31-40$ & .12237 & .093 \\
& 1 lebih 40 thn & $.30809^{*}$ & .000 \\
& $1-10$ & $-.12914^{*}$ & .000 \\
\multirow{3}{*}{ 31-40 Tahun } & $11-20$ & $-.08547^{*}$ & .030 \\
& $31-40$ & .03690 & .956 \\
& 1 lebih 40 thn & $.22262^{*}$ & .025 \\
& $1-10$ & $-.16604^{*}$ & .009 \\
lebih 40 thn & $11-20$ & -.12237 & .093 \\
& $21-30$ & -.03690 & .956 \\
& lebih 40 thn & .18571 & .181 \\
& $1-10$ & $-.35176^{*}$ & .000 \\
& $11-20$ & $-.30809^{*}$ & .000 \\
& $21-30$ & $-.22262^{*}$ & .025 \\
& $31-40$ & -.18571 & .181 \\
\hline
\end{tabular}

*Signifikan pada aras keertian 0.05

Seterusnya, dapatan analisis data dalam jadual 4.06, menunjukkan keputusan ujian ANOVA Berganda bagi pembolehubah kualiti pengajaran berdasarkan pengalaman mengajar. Data ini menunjukkan bahawa terdapat perbezaan yang signifikan kualiti pengajaran berdasarkan pengalaman mengajar dan didapati antara kumpulan guru yang mempunyai pengalaman mengajar 1 hingga 10 tahun dengan guru yang mempunyai pengalaman mengajar 21 hingga 30 tahun $[(\mathrm{I}-\mathrm{J})=.12 ; P<.05]$.

Perbezaan juga dapat dilihat antara kumpulan pengalaman mengajar 1 hingga 10 tahun dengan guru yang mempunyai pengalaman mengajar 31 hingga 40 tahun [(I-J) $=.16 ; P<.05]$. Seterusnya perbezaan juga dapat dilihat antara kumpulan pengalaman mengajar 1 hingga 10 tahun dengan kumpulan yang mempunyai pengalaman mengajar lebih daripada 40 tahun [(I$\mathrm{J})=.30 ; P<.05]$. Seterusnya perbezaan juga dapat dilihat dalam kumpulan pengalaman mengajar 11 hingga 20 tahun dengan guru yang mempunyai pengalaman mengajar melebihi 40 tahun $[(\mathrm{I}-\mathrm{J})=.30 ; P<.05]$. akhir sekali perbezaan juga dapat dilihat dalam kumpulan guru 
yang mempunyai pengalaman mengajar 21 hingga 30 tahun dengan kumpuln guru yang mempunyai pengalaman mengajar lebih daripada 40 tahun [(I-J) $=.22 ; P<.05]$. Dapatan ini menunjukkan bahawa $\mathrm{H}_{\mathrm{o}}$ 2(iii) adalah ditolak.

\section{Perbincangan dan Implikasi kajian}

Secara keseluruhannya kajian ini mendapati bahawa tidak terdapat perbezaan yang signifikan kualiti pengajaran guru berdasarkan faktor umur. Walau bagaimanapun skor min kualiti pengajaran yang paling tinggi dicatatkan dalam kumpulan umur guru 44 hingga 53 tahun. Ini menunjukkan bahawa semakin tinggi umur seseorang itu semakin tinggi kualiti pengajarannya. Dapatan ini disokong oleh kajian Kartini, Zulkifley, Pareeda \& Suhaila (2015), yang jelas sekali menunjukkan bahawa tahap umur, etnik, persekitaran dan pelbagai pemboleh ubah lain akan mempengaruhi pemikiran dan tindakan seseorang individu.

Dapatan kajian ini juga menunjukkan bahawa kualiti seseorang guru dapat ditentukan dengan umur seseorang guru, hal ini demikian kerana guru yang berkualiti tidak semestinya seorang guru yang mempunyai pelbagai kemahiran baharu, tetapi guru yang berkualiti juga diambil kira berdasarkan seseorang guru yang dapat mengena lpasti skill atau kemahiran pelajar untuk memahami perkara yang disampaikan oleh guru. Seorang guru berkualiti misalnya boleh menghafal semua fakta dan menerangkannya kepada pelajar tanpa sebarang teks atau rujukan, namun tidak semua pelajar dapat memahami ilmu yang cuba disampaikan. Berbeza dengan seorang guru yang mengajar mengikut kemampuan pelajar untuk memahami ilmu yang disampaikan.

Di samping itu, dapatan kajian menunjukkan bahawa terdapat perbezaan yang signifikan kualiti pengajaran berdasarkan kelulusan akademik. Skor min yang paling tinggi dicatatkan dalam kalangan guru yang mempunyai kelulusan akademik tertinggi peringkat Ijazah Sarjana Muda. Dapatan ini bertepatan dengan kajian yang dilaksanakan oleh Goe (2007) yang mendapati bahawa kualiti seseorang guru salah satunya diukur berdasarkan kelayakan akademiknya.

Selain itu kualiti guru yang mempunyai keupayaan dan kecekapan dalam menggunakan sumber digital dalam pengajaran dan pembelajaran mampu menyediakan persekitaran pengajaran dan pembelajaran yang memberi peluang dan ruang kepada pelajar untuk meneroka, mentafsir, dan mencari makna di sebalik bahan bukti (Bolick \& McGlinn, 2004; Endacott, 2010; Sandwell, 2004; Schrum, 2001).

Dapatan ini juga tidak sejajar dengan kajian yang telah dijalankan oleh Horton (2013); Korthagen (2005); Leithwood (1997); Leithwood, Harris (2010) dan Hopkins (2001) serta Robinson, V. Hohepa, M. \& Lloyd, C. (2009) menunjukkan pembangunan profesional adalah bidang yang mempengaruhi pencapaian dan kecemerlangan pelajar. Hal ini demikian kerana pembengunan profesional guru juga dapat dilihat dengan adanya guru yang mempunyai kelayakan akademik yang tinggi dan sentiasa menguasai perubahan.

Kajian ini turut mendapati bahawa terdapat perbezaan yang signifikan kualiti pengajaran berdasarkan Pengalaman mengajar guru. Dapatan ini selari dengan dapatan kajian Seligmen (2001), semakin berpengalaman seseorang guru itu, semakin positif pandangan mereka terhadap perkara-perkara negatif dan mereka akan berasa lebih selesa terhadap sebarang perubahan. 
Dapatan ini juga turut menyokong kajian Giancola (2001) yang mendapati bahawa keterampilan guru dalam pengajaran diperolehi melalui latihan dan pengalaman. Pengalaman dan latihan merupakan komponen yang penting dalam inovasi. Bagaimana pun dalam kajian ini turut mendapati bahawa skor min guru yang mempunyai pengalaman mengajar melebihi 40 tahun akan semakin menurun. Hal ini demikian disebabkan oleh faktor kesihatan dan faktor tekanan yang dihadapi oleh guru-guru yang telah lama berkhidmat sebagaimana kajian yang pernah dijalankan oleh Evens et.al (2002), di Belanda yang mendapati bahawa tekanan dalam kalangan guru-guru akan meningkat akibat daripada perubahan yang drastik da inovasi dalam pengajaran.

Guru-guru yang tidak dilahirkan dalam era teknologi dan globalisasi agak sukar untuk beradaptasi dengan ledakan teknologi maklumat, tambahan pula dalam usia yang sudah bertambah. Justeru dilihat dalam kajian ini, walaupun terdapat perbezaan yang signifikan kualiti pengajaran berdasarkan pengalaman mengajar, tetapi dilihat skor min kualiti pengajaran berdasarkan pengalaman mengajar menjadi rendah dalam kalangan guru-guru yang mempunyai pengalaman mengajar melebihi 40 tahun.

\section{Kesimpulan}

Kajian ini menyingkap tentang perbezaan antara kualiti pengajaran dan faktor demografi. Faktor demografi yang termasuk dalam kajian ini ialah faktor umur, faktor kelulusan akademik dan faktor pengalaman mengajar. Dapatan kajian mendapati bahawa tidak terdapat kaitan antara kualiti pengajaran seseorang guru dengan faktor umur. Tetapi terdapat perbezaan antara kualiti pengajaran guru dengan faktor kelulusan akademik dan factor pengalaman mengajar. Pihak sekolah sudah semestinya memberikan penekanan terhadap kualiti pengajaran. Hal ini demikian kerana, saban tahun pemantauan pihak-pihak tertentu terhadap kualiti pengajaran dilaksanakan dari semasa ke semasa.Walau bagaimanapun dalam kajian ini mendapati, kualiti pengajaran bukanlah punca utama kepada meningkatnya pencapaian Bahasa Melayu, tetapi turut disebabkan oleh faktor-faktor lain yang turut menyumbang kepada peningkatan pencapaian tersebut.

Walaupun masih tidak banyak kajian yang dilakukan di sekolah-sekolah bandar khususnya memperlihatkan bahawa pelajar-pelajar lebih menguasai mata pelajaran Bahasa Inggeris berbanding Bahasa Melayu. Pihak yang berwajib seharusnya memastikan pencapaian dalam kedua-dua mata pelajaran ini adalah seiring. Kajian terhadap faktor demografi guru dan pelajar perlu dititikberatkan. Hal ini demikian kerana kajian berkenaan dapat menyumbang kepada perancangan pendidikan di sekolah yang lebih tersusun dan berkesan.

\section{Rujukan}

Abdul Rahim Abdul Rashid. 2007. Wawasan dan Agenda Pendidikan. Kuala Lumpur: Utusan Publications \& Distibutors Sdn Bhd.

Alias Baba. 1999. Statistik Penyelidikan Dalam Pendidikan Dan Sains Sosial. Bangi: Universiti Kebangsaan Malaysia

Bartlett, J.E., Kotrlik, J.W., and Higgins, C.C. 2001. Organizational Research: Determining Appropriate sample Size in Survey Research. Information Technology, Learning, and Performance Journal, 19(1), pp 43-50

Bolick, C. M., \& McGlinn, M. M. 2004. Harriet Jacobs: Using online slave narratives in the classroom. Social Education, 68(3), 198-202.

Brophy. J.2000. Motivating Students to Learn. Boston: McGraw-Hill Co. Inc. 
Cohen, L., Manion, L., \& Morrison, K.2007. Research Methods in Education, 2 ${ }^{\text {nd }}$ Edition.New York: Routledge

Evens, W.J.G. Brouwers, A \& Tomic, W. 2002. Burnout and self efficacy: A Study On Teachers belief When Implementing an Innvative Educational system in the Netherlands. British Journal of Educational Psychology.72:227-243.

Endacott, J. 2010. Reconsidering affective engagement in historical empathy. Theory and Research in Social Education, 38(1), 6-49.

Goe, 1. \& Stickler, 1. M. 2008. Teacher Quality and Student Achievemant: Making the Most of Recent Research. TQ Research \& Policy Brief. national Comprehensive Center for Teacher Quality.

Giancola, O. \& Fornari, R. 2011. Policies for Decentralization, School Autonomy and Inequalities in Educational Performance among the Italian Regions: Empirical evidence from Pisa 2006, Italian Journal of Sociology of Education, 8(2), 150 172. http://www.ijse.eu/index.php/ijse/article/view/111

Harris, A. 2010. Leading system transformation. School leadership and management 30(3) 197-207

Huberman, M. 1993. The Lives of Teachers (J. Neufeld, Trans.) London: Cassell Villiers House.

Hopkins, D. 2001. School improvement for real. London: Falmer Press

Kartini Wado, Zulkifley Hamid, Pareeda Hayeeteh \& Suhaila Binsama-ae. 2015. Pengajaran bahasa Melayu baku dalam komuniti perbatasan: Satu kajian pengaruh dialek Patani di Selatan Thailand. Geografia Online - Malaysian Journal of Society and Space, 11 (11): 36-44.

Kington, A., Sammons, P., Day, C., Regan, E. 2011. 'Stories and statistics: describing a mixed methods study of effective classroom practice'. Journal of mixed methods research, 5(2) 103-125.

Korthagen, F. A. J. 2004. In search of the essence of a good teacher: Towards a more holistic approach i teacher education. Teaching and Teacher Education, 20, 77-97.

Krejcie, R.\& Morgan, D.W.1970. Determining Sampel size for Research activities. Educational and Psychological Measurement, 30 (3),607-610.

Leithwood, K., Steinbach, R., \& Jantzi, D. 2002. School leadership and teachers' motivation to implement accountability policies. Educational Administration Quarterly, 38(1), 94-115.

Marzita Puteh. 2013. Isu-Isu Kontemporari Dalam Pendidikan. Kuala Lumpur: Institut Kajian Dasar.

Muhyiddin Haji Mohd Yassin. 2012. Sudut Pandang Muhyiddin Yassin; isu, kontroversi, pandangan serta harapan: sebuah wawancara. Institut Terjemahan Negara Malaysia. Kuala Lumpur.

Robinson, V., Hohepa, M. \& Lloyd, C. (2009) School leadership and student outcomes: identifying what works and why. Best Evidence Syntheses Iteration (BES). New Zealand: Ministry of Education. [online] Available from: http://www.educationcounts.govt.nz/publications/series/2515/60169/60170

Sandwell, R. 2004. "Who killed William Robinson?" Exploring a nineteenth century murder online. Social Education, 68(3), 210-213.

Schrum, K. (2001). Making history on the web matter in your classroom. The History Teacher, 34(3), 327-338.

Seligman, M. E. P., \& Csikszentmihalyi, M. 2001. Positive psychology: An introduction: American Psychologist, 56(1), 89-90.

Yusfarina \& Abdul Rasid. 2011. Bahasa Melayu kini. Dewan Bahasa 11(04): 10-14. 